\title{
Root Radial Oxygen Loss and the Effects on Rhizosphere Microarea of Two Submerged Plants
}

\author{
Cuicui Tian ${ }^{1,2}$, Chunbo Wang ${ }^{1,2}$, Yingying Tian ${ }^{1,2}$, Xingqiang Wu${ }^{1}$, Bangding Xiao* \\ 'Key Laboratory of Algal Biology of Chinese Academy of Sciences, Institute of Hydrobiology, \\ Chinese Academy of Sciences, Wuhan 430072, China \\ ${ }^{2}$ University of Chinese Academy of Sciences, Beijing 100049, China
}

Received: 7 January 2015

Accepted: 5 March 2015

\begin{abstract}
Radial oxygen loss (ROL) has been suggested to be a major process to protect plants exposed to the anaerobic by-products of soil anaerobiosis. The aim of the present study was to test the effects of root ROL from two submerged plants (Hydrilla verticillata and Vallisneria spiralis) on the rhizosphere oxygen profile and rhizosphere microarea. Phospholipid fatty acids (PLFAs) of sediment samples were used to characterize and quantify the microbial community. The results showed clearly that there were significant differences between the two plants in radial oxygen loss, which affected rhizosphere physicochemical parameters and the microbial community. Rhizosphere total biomass, bacteria, gram-positive bacteria, actinomycetes, and microbial diversity of $V$. spiralis were significantly higher than those of $H$. verticillata. The present study highlights root ROL as a key parameter affecting the microbial community of the rhizosphere microarea.
\end{abstract}

Keywords: root radial oxygen loss, phospholipid fatty acids, rhizosphere, microbial community, submerged plant

\section{Introduction}

Submerged plants are essential constituents and primary manufacturers in the water ecological system, and play a regulatory role in the ecological system of material circulation and energy [1]. Since flooded soils are generally oxygen deficient and dominated by anaerobic microflora, they are a potentially hostile environment for the roots of submerged plants [2]. However, due to the presence of aerenchyma in roots and stems [3], oxygen is transported to roots and some of this leaks into the anaerobic sediment. This radial oxygen loss (ROL) is one of the most important functional characteristics of submerged plants, which may relate to their adaptability to the wetland substrate [4] and

*e-mail: bdxiao@ihb.ac.cn to their ability to remove nutrients in anoxic conditions [2]. When submerged plant roots release oxygen into the sediment, an aerobic-anaerobic gradient with some distance away from the roots is formed, where aerobic, anaerobic, and facultative anaerobic microorganisms can co-exist [2, 5].

The rhizosphere is where physicochemical and microbial processes take place that are induced by the interaction of plants, microorganisms, sediment, and pollutants [4]. The role of ROL in wetland microbial ecology is probably essential because it has the potential to establish steep redox gradients that specific groups of microbes exploit to oxidize methane, $\mathrm{NH}_{4}^{+}, \mathrm{Fe}^{2+}$, or organic matter $[6,7]$, therefore affecting the rhizosphere microbial community. Root ROL and the rhizosphere microbial population promote plant growth and health by facilitating the breakdown of organic 
matter, mineralizing nutrients $[8,9]$ and protecting from phytotoxins such as $\mathrm{S}_{2}^{-}$and $\mathrm{Fe}^{2+}[7,10,11]$. So the study of microbial communities associated with plant ROL is important for understanding their ecological role in natural environments [12].

Hydrilla verticillata (H. verticillata) and Vallisneria spiralis (V. spiralis) (Hydrocharitaceae) are two perennial submersed plants widely used in lake ecological restoration. They tolerate a wide range of environmental conditions, making them suitable pioneer species for inclusion in restoration projects to reverse the eutrophication of lakes $[13,14]$.

The objectives of this study were to study ROL from the root of $H$. verticillata and $V$. spiralis and analyze the possible influences on the microbial community structure and diversity and on chemical transformations in the sediment. The microbial community was assessed by analyzing sediment for characteristic phospholipid fatty acids (PLFAs) [15-17]. The effects of ROL on sediment and rhizosphere oxygen and redox levels were revealed using microelectrodes, while ROL from whole root systems was determined using titanium citrate [18].

\section{Materials and Methods}

\section{Experiment Plants and Sediment}

$H$. verticillata used in the present experiment was collected from Lake Caohai, China. V. spiralis was collected from Lake Donghu, China. All samples were placed in separate air-sealed plastic bags and transported to a laboratory as soon as possible, and each sample was rinsed with tap water several times and then inoculated indoors at room temperature.

Sediment was collected from Donghu Lake, Wuhan Province, China. The sediment was ground to pass through an 80-mesh sieve, and analyzed for the following parameters prior to the plant growth experiment: total nitrogen (TN $\left.2.34 \pm 0.01 \mathrm{mg} \cdot \mathrm{g}^{-1}\right)$ using the Kjeldahl method; total phosphorus (TP $2.05 \pm 0.07 \mathrm{mg} \cdot \mathrm{g}^{-1}$ ) using the molybdenum blue method [19]; total $\mathrm{Fe}\left(21.74 \pm 0.41 \mathrm{mg} \cdot \mathrm{g}^{-1}\right)$ were determined using the modified 2, 2,-bipyridyl spectrophotometric method [20]; organic content $(12.78 \pm 0.13 \%)$ as loss on ignition at $550^{\circ} \mathrm{C}$; and sediment porosity $(0.20 \pm 0.03)$ and $\mathrm{pH}$ using a $\mathrm{pH}$ microelectrode (Unisense, 6.97 \pm 0.22 ).

\section{Microcosm Experiments}

The experiment contained seven microcosms (Fig. 1), each of which was comprised of an aquarium (inner size: $40 \times 28 \times 15 \mathrm{~cm})$ with thirty cylindrical plastic cups $(5 \mathrm{~cm}$ diameter and $8 \mathrm{~cm}$ height). Three replicate microcosms were used throughout the experiment for each plant, while a microcosm without submerged plants served as a control. About $5 \mathrm{~cm}$ depth sediment was filled in and outside the cups. Three plant seedlings (about $10 \mathrm{~cm}$ ) were then planted in each cup. The microcosms were placed in a greenhouse and incubated at $25 \pm 1^{\circ} \mathrm{C}$ under a $12 / 12 \mathrm{~h} \mathrm{light/dark}$ cycle. The illuminations were about 1,500 lux during the day and 0 in darkness. In addition, tap water was added daily to replenish water lost from evaporation. The experiment lasted 60 days with sampling first at 20 days and every 10 days thereafter.

\section{Sediment and Plant Sampling}

The characters of sediment and plant were traced after 20 days when $H$. verticillata seedlings began rhizogenesis. At each sampling, six cups in each microcosm were randomly selected. Firstly, one of which was used for the in situ measurement of oxygen and redox potential (Eh) profiles and in vitro measurement of root inner oxygen 60 days after replanting.

Previous studies had defined the sediment within a $4 \mathrm{~mm}$ distance around the root as the rhizosphere sediment $[9,21]$. After the plants were carefully extracted, the sediment attached to the roots was collected and deemed as rhizosphere sediment in this study. Control sediment was defined as sediment without plants, and was sampled at 3-4 cm depth. Sediment samples were analyzed for chemical parameters and PLFAs. Before PLFA analysis, fresh sediment samples were immediately freeze-dried, ground and passed through an 80 mesh sieve and stored at $-20^{\circ} \mathrm{C}$.

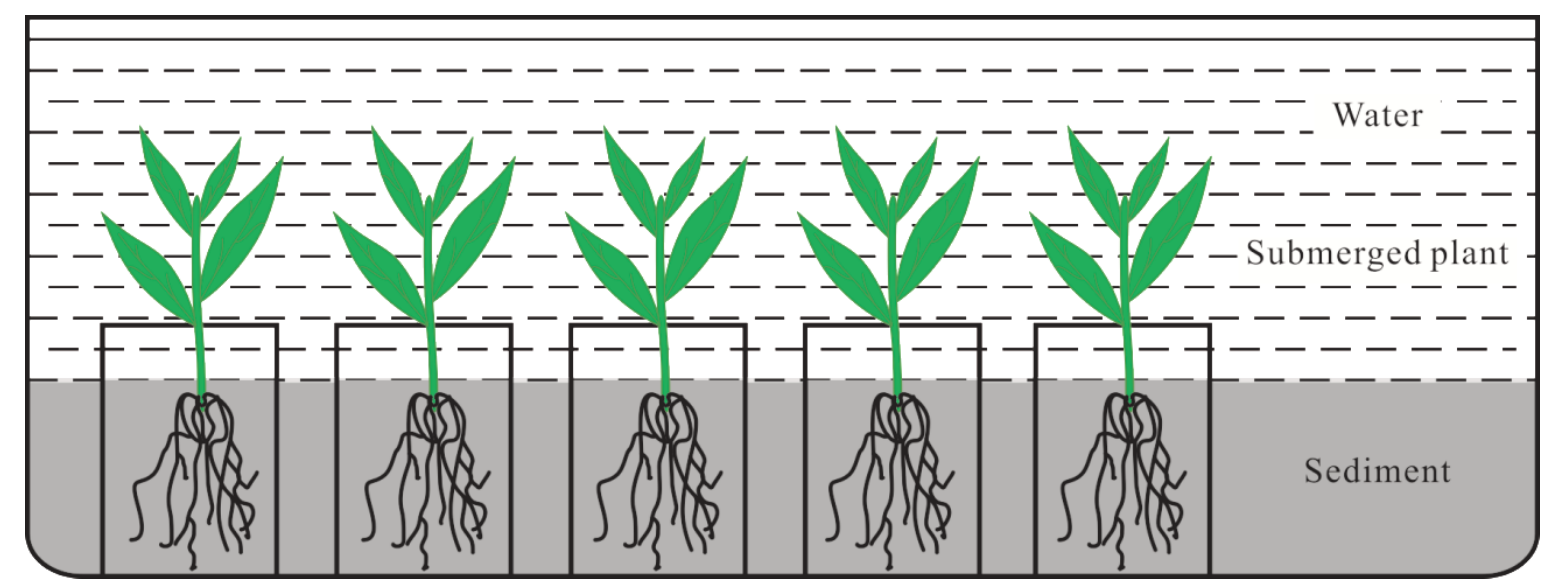

Fig. 1. Diagram of the microcosm experiment. 
The plant samples were also collected and rinsed thoroughly with deionized water for the measurement of root ROL. After ROL measurement, each plant sample was washed carefully with deionized water and then separated into roots and shoots (including leaves and stems). Some fresh roots were used for porosity determination, and the remaining roots and shoots were weighted after drying $\left(24 \mathrm{~h}\right.$ at $\left.80^{\circ} \mathrm{C}\right)$ to a constant weight to obtain the final dry mass $(\mathrm{dw})$.

\section{Analytical Methods}

The oxygen and Eh profiles of the water-sediment interface were measured by microelectrodes (OXY25, $\varnothing=25 \mu \mathrm{m}$, RO100, $\varnothing=100 \mu \mathrm{m}$, Unisense, Denmark). The oxygen electrode is connected to an OXY-meter (a high-sensitivity picoampere amplifier, Unisense) and the cathode is polarized against the internal reference. The reference electrode of Eh electrode is a simple open-ended $\mathrm{Ag}-\mathrm{AgCl}$ electrode with a gel-stabilized electrolyte (Unisense) and is used to establish a reference potential against the redox microelectrode. A motor controller (MC-232, Unisense) with a micromanipulator (MM 33, Unisense) was connected with microelectrodes and a computer. The measurements of water-sediment oxygen and Eh profiles were performed in the center of the range at a distance of about $2 \mathrm{~mm}$ from the plants. The spatial resolutions of all measurements were $500 \mu \mathrm{m}$ in depth. The periods for "wait before measure" and "measure" were both set as $3 \mathrm{~s}$ for $\mathrm{O}_{2}$ and $10 \mathrm{~s}$ for Eh.

Oxygen microelectrodes are nowadays widely used in plant science to measure oxygen concentrations in tissues such as rice roots [9]. Root inner oxygen contents were measured by oxygen microelectrode (OXY25, $\varnothing=25 \mu \mathrm{m}$, Unisense, Denmark). After the in situ measurement of $\mathrm{O}_{2}$ and Eh profiles at 60 days, plants were transferred to a stagnant solution containing 1\% (w/v) agar in Hoagland's solution [22] and was deoxygenated by $\mathrm{N}_{2}$ gas before use, followed immediately by covering the solution surface with $0.5 \mathrm{~cm}$ of paraffin liquid to prevent atmospheric $\mathrm{O}_{2}$ [9] (Fig. 2). After $2 \mathrm{~h}$, the inner oxygen produced by individual roots was measured by microelectrode $1 \mathrm{~cm}$ from the root apex.

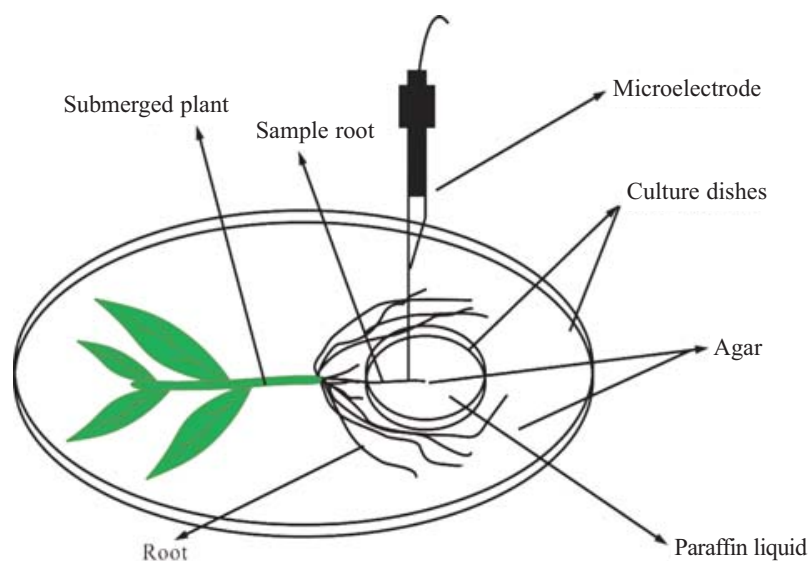

Fig. 2. Diagram of the measurement of the inner oxygen produced by individual roots in an agar microcosm.
Root ROL of each plant was quantified by the $\mathrm{Ti}^{3+}$ citrate method [18]. Briefly, $30 \mathrm{~mL} \mathrm{TiCl}_{3}(1.16 \mathrm{M})$ was added to a $200 \mathrm{mM}$ deoxygenated sodium citrate $(300 \mathrm{~mL})$ to form a $\mathrm{Ti}^{3+}$-citrate solution. $\mathrm{pH}$ was adjusted to 5.6 with saturated $\mathrm{NaHCO}_{3}$ solution. Plant samples were washed carefully and then inserted into $50 \mathrm{~mL}$ tubes with roots completely immersed in $40 \mathrm{~mL}$ deoxygenated 10\% Hoagland's solution [22]. Subsequently, $\mathrm{Ti}^{3+}$-citrate solution was added to the tubes, followed immediately by covering the solution surface with $2 \mathrm{~cm}$ of paraffin oil to prevent oxidation by atmospheric $\mathrm{O}_{2}$. The test tubes were incubated at $25^{\circ} \mathrm{C}$ under 1,500 lux illumination. After $6 \mathrm{~h}$, all tubes were shaken gently and the solutions were measured at $527 \mathrm{~nm}$ using a UVvisible spectrophotometer. The amount of released $\mathrm{O}_{2}$ was determined based on $\mathrm{Ti}^{3+}$-citrate oxidation. Root ROL was calculated according to the following formula:

$$
\mathrm{ROL}=1000 c(y-z) / g / \mathrm{T}
$$

...where $c$ is the initial volume of $\mathrm{Ti}^{3^{+}}$-citrate added to each tube (L), $y$ is the concentration of $\mathrm{Ti}^{3+}$-citrate solution without plants $(\mathrm{mM}), z$ is the concentration of $\mathrm{Ti}^{3+}$-citrate solution with plants $(\mathrm{mM}), \mathrm{g}$ is root dry weight $(\mathrm{g})$, and $\mathrm{T}$ is response time (h).

Root porosity was measured according to the method described by Kludze et al. [18]. About $0.6 \mathrm{~g}$ of fresh roots (1-3 cm from the root apex) was used for porosity determination. Porosity was calculated using the following equation:

$$
\text { Porosity }(\%)=[(P v r-P r) /(r+P-P r)] \times 100
$$

...where $P v r$ is the mass of pycnometer with vacuumed roots and water $(\mathrm{g}), \mathrm{Pr}$ is the mass of pycnometer with water and fresh roots $(\mathrm{g}), r$ is the mass of fresh roots $(\mathrm{g})$, and $P$ is the mass of pycnometer with water $(\mathrm{g})$.

Fresh sediment samples were extracted with $2 \mathrm{~mol} \cdot \mathrm{L}^{-1}$ $\mathrm{KCl}$ and saturated $\mathrm{CaSO}_{4}$ (sediment:solution ratio 1:10), and the extracts were measured respectively for $\mathrm{NH}_{4}^{+}$and $\mathrm{NO}_{3}^{-}$[23]. Total $\mathrm{Fe}$ and $\mathrm{Fe}^{2+}$ in the extract were determined using a modified 2, 2,-bipyridyl spectrophotometric method [20] after digestion with $\mathrm{HCl}(3 \mathrm{M})$ for $16 \mathrm{~h}$, and analyzed at $520 \mathrm{~nm}$.

The microbial communities of rhizosphere and control sediment at 60 days were characterized using PLFA analysis according to Bossio and Scow [24]. Briefly, lipids were extracted twice from freeze-dried sediment using phosphate buffer (50 mM, pH 7.4), chloroform, and methanol at a ratio of $0.8: 1: 2$. Supernatant from the second extraction was added to the first. Samples were shaken and the phases were allowed to separate overnight. The organic phase was decanted and evaporated under $\mathrm{N}_{2}$ at $30^{\circ} \mathrm{C}$. The resulting lipid material was fractionated into neutral lipids, glycolipids, and polar lipids on a silica gel SPE column (Agilent SPE 5982-2265, USA) by elution with chloroform, acetone, and methanol, respectively. Methanol was evaporated under $\mathrm{N}_{2}$ at $30^{\circ} \mathrm{C}$. After mild methanolic $\mathrm{KOH}$ to form fatty acid methyl esters (FAMEs), samples were then dissolved in hexane-containing methyl nonadecanoate fatty acid (19:0) as an internal standard and analyzed in an Agilent 6890N gas chromatograph (Wilmington, USA) with MIDI 
Table 1. Differences in morphological parameters and ROL of two different plants.

\begin{tabular}{|c|c|c|c|c|c|c|}
\hline $\begin{array}{c}\text { Time } \\
(\mathrm{d})\end{array}$ & Species & $\begin{array}{c}\text { Root biomass } \\
(\mathrm{mg} \mathrm{dw})\end{array}$ & $\begin{array}{c}\text { Shoot biomass } \\
(\mathrm{mg} \mathrm{dw})\end{array}$ & $\begin{array}{c}\text { Root inner oxygen } \\
\left(\mu \mathrm{mol} \cdot \mathrm{L}^{-1}\right)\end{array}$ & $\begin{array}{c}\text { Root porosity } \\
(\%)\end{array}$ & $\begin{array}{c}\text { ROL } \\
\left(\mu \mathrm{mol}_{2} \cdot \mathrm{h}^{-1} \cdot \mathrm{g}^{-1} \mathrm{dw} \text { root }\right)\end{array}$ \\
\hline \multirow{2}{*}{20} & H. verticillata & $2.52 \pm 0.83^{\mathrm{a}}$ & $36.37 \pm 15.15^{\mathrm{a}}$ & - & - & $35.61 \pm 4.46^{\mathrm{a}}$ \\
\cline { 2 - 7 } & V. spiralis & $3.10 \pm 0.41^{\mathrm{a}}$ & $26.88 \pm 2.89^{\mathrm{a}}$ & - & - & $39.72 \pm 5.62^{\mathrm{a}}$ \\
\hline \multirow{2}{*}{30} & H. verticillata & $4.76 \pm 0.72^{\mathrm{a}}$ & $55.49 \pm 14.95^{\mathrm{a}}$ & - & - & $41.76 \pm 8.49^{\mathrm{a}}$ \\
\cline { 2 - 7 } & V. spiralis & $4.95 \pm 0.75^{\mathrm{a}}$ & $69.19 \pm 13.02^{\mathrm{a}}$ & - & - & $66.24 \pm 5.18^{\mathrm{b}}$ \\
\hline \multirow{2}{*}{40} & H. verticillata & $6.81 \pm 0.90^{\mathrm{a}}$ & $73.89 \pm 10.34^{\mathrm{a}}$ & - & - & $45.69 \pm 8.93^{\mathrm{a}}$ \\
\cline { 2 - 7 } & V. spiralis & $7.44 \pm 0.77^{\mathrm{a}}$ & $69.19 \pm 13.02^{\mathrm{a}}$ & - & - & $68.03 \pm 4.32^{\mathrm{b}}$ \\
\hline \multirow{2}{*}{50} & H. verticillata & $8.09 \pm 0.33^{\mathrm{a}}$ & $134.32 \pm 20.66^{\mathrm{a}}$ & - & - & $65.69 \pm 2.71^{\mathrm{a}}$ \\
\cline { 2 - 7 } & V. spiralis & $14.73 \pm 1.64^{\mathrm{b}}$ & $149.36 \pm 28.03^{\mathrm{a}}$ & - & - & $-3.30 \pm 5.79^{\mathrm{b}}$ \\
\hline \multirow{2}{*}{60} & H. verticillata & $12.23 \pm 3.82^{\mathrm{a}}$ & $209.00 \pm 7.32^{\mathrm{a}}$ & $79 \pm 1^{\mathrm{a}}$ & $22.56 \pm 1.26^{\mathrm{a}}$ & $66.61 \pm 8.10^{\mathrm{a}}$ \\
\cline { 2 - 7 } & V. spiralis & $15.60 \pm 1.80^{\mathrm{a}}$ & $211.40 \pm 14.74^{\mathrm{a}}$ & $103 \pm 10^{\mathrm{b}}$ & $26.76 \pm 2.26^{\mathrm{b}}$ & $78.51 \pm 6.65^{\mathrm{b}}$ \\
\hline
\end{tabular}

means \pm SD with three replicates, small letters in the same column represent significant differences between two plants, $\mathrm{P}<0.05$

peak identification software (version 6.2, MIDI, Newark, USA) and an Agilent 19091B-102 (25.0 m×200 $\mu \mathrm{m} \times 0.33$ $\mu \mathrm{m})$ capillary column.

The total amount of PLFAs was used to indicate the total microbial biomass, and the amounts of the different PLFA biomarkers were used to represent the different groups of sediment microorganisms. The sum of the following PLFA biomarkers were considered to represent bacterial origin (Gram-positive bacteria by i14:0, i15:0, a15:0, i16:0, a16:0, a17:0, Gram-negative bacteria by $18: 1 \omega 5 \mathrm{c}$, $18: 1 \omega 7 \mathrm{c}$, bacteria were represented by the sum of the two) [25]. Biomarkers $18: 1 \omega 9 c, 18: 3 \omega 6 c$, and $16: 1 \omega 5 c$ were used for indicating fungi, and 10Me16:0 and 10Me17:0 were used as a marker for actinomycetes [16, 26]. Diversity indices were calculated as:

$$
\text { Shanon index }(\mathrm{H})=-\Sigma p_{i} \ln \left(p_{i}\right)
$$

...where $p_{i}$ is the relative abundance of PLFA.

\section{Statistical Analysis}

Quantitative data was expressed as means \pm SD. Data were analyzed using SPSS 19.0. One-way analysis of variance (ANOVA) followed by post-hoc least significant difference (LSD) testing was used to assess the effect of plant species on physicochemical parameters, total biomass, and PLFA biomarkers. Statistical significance was set at the $\mathrm{P}<0.05$ level.

\section{Results}

\section{Characteristics of Plant Growth and Root ROL}

Root biomass, shoot biomass and root ROL increased with time (Table 1). Major external morphological parameters such as root and shoot biomass for $V$. spiralis were greater than those for $H$. verticillata, but were not statistically significant $(\mathrm{P}>0.05)$, except for the differences in the root dry weights at 50 days after replanting $(\mathrm{P}<0.05)$. As measured by the $\mathrm{Ti}^{\mathrm{i}^{+}}$-citrate method, ROL of $V$. spiralis was significantly higher than that of $H$. verticillata (except at 20 days).

The oxygen value decreased rapidly in the agar and reached near zero at a distance of approximately $500 \mu \mathrm{m}$ from the agar surface (data not shown). When the microelectrode reached within the root, oxygen concentrations were about 79 and $103 \mu \mathrm{mol} \cdot \mathrm{L}^{-1}$ for $H$. verticillata and $V$. spiralis. These results indicated that root internal morphological parameters such as aerenchyma might promote oxygen release from the root to the rhizosphere sediment. The root porosities were $22.56 \%$ and $26.76 \%$ for $H$. verticillata and $V$. spiralis, respectively.

\section{Characteristics of the Rhizosphere Oxygen and Eh with Different Plants}

To investigate the real status of the rhizosphere oxygen distribution in rhizosphere sediment, the oxygen concentration profiles were detected in situ for both $H$. verticillata and $V$. spiralis. The oxygen dissolved in the water layer remained stable at approximately $224 \mu \mathrm{mol} \cdot \mathrm{L}^{-1}$ for $\mathrm{H}$. verticillata and $250 \mu \mathrm{mol} \cdot \mathrm{L}^{-1}$ for $V$. spiralis, compared with 203 $\mu \mathrm{mol} \cdot \mathrm{L}^{-1}$ in the control sediment (Fig. 3). The content of oxygen decreased rapidly in the sediment and reached to 0 at a distance of approximately $3.5-8.5 \mathrm{~mm}$ from the watersediment interface. The thickness of aerobic layer decreased in the order $V$. spiralis $>H$. verticillata $>$ control sediment, suggesting that plants can improve rhizosphere sediment oxygen concentrations and the amount of dissolved oxygen in the water layer. When the microelectrode was in contact with the root surface, a peak appeared at about $15 \mathrm{~mm}$ under the water-sediment interface (Fig. 3a). Because the root inner oxygen concentrations (Table 1) were significantly higher than this peak, it could also veri- 

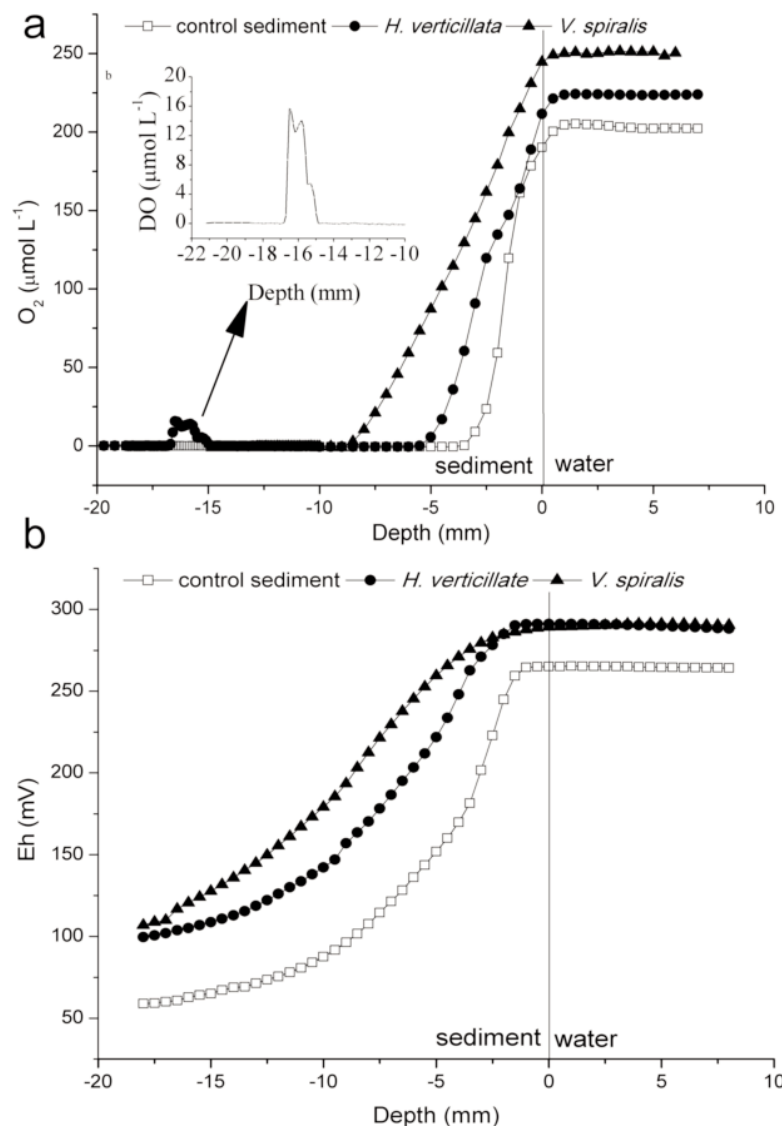

Fig. 3. Oxygen and redox potential profiles of the rhizosphere sediment ( $2 \mathrm{~mm}$ away from the root surface) and the control (without plants) 60 days after planting in Lake Donghu sediment with $H$. verticillata and $V$. spirals.

fy the existence of root ROL, which made a microarea "oxidation ring" around the roots.

Eh values underwent similar trends (Fig. 3b), with a clear distinction between water and sediment. Eh values of planted sediments were higher than those of control sediment, especially for $V$. spiralis with higher ROL, which meant the potential for loss of oxygen to sediment through root ROL that could improve sediment Eh conditions.

\section{Changes to Chemical Parameters}

$\mathrm{NH}_{4}^{+}$concentrations in the rhizosphere sediment were significantly lower than those in control sediment (Fig. 4a), suggesting that, in some way, the presence of roots was responsible. The average $\mathrm{NH}_{4}^{+}$concentration of the sediment in the control was $3.19 \mathrm{mg} \cdot \mathrm{kg}^{-1}$, while the rhizosphere sediments were 1.54 and $1.29 \mathrm{mg} \cdot \mathrm{kg}^{-1}$ for $H$. verticillata and V. spiralis, respectively.

Unlike $\mathrm{NH}_{4}^{+}$, the $\mathrm{NO}_{3}^{-}$concentrations in the rhizosphere were higher than those in the control sediment during the different sampling dates (Fig. 4b). The average $\mathrm{NO}_{3}^{-}$concentrations of the sediment in the rhizosphere sediment were 0.68 and $0.73 \mathrm{mg} \cdot \mathrm{kg}^{-1}$ of the two plants, while the control was $0.63 \mathrm{mg} \cdot \mathrm{kg}^{-1}$.
Total Fe did not change with time among rhizosphere and control sediment (Fig. 4c). $\mathrm{Fe}^{2+}$ was oxidized by root ROL and changed to $\mathrm{Fe}^{3+}$. $\mathrm{Fe}^{2+}$ in control sediment was significantly higher than the rhizospheres of $H$. verticillata and V. spiralis.

\section{Microbial Community Structure Assessed by PLFAs}

The PLFA profiles of the whole microbial community structure showed that the samples collected from sediment

a

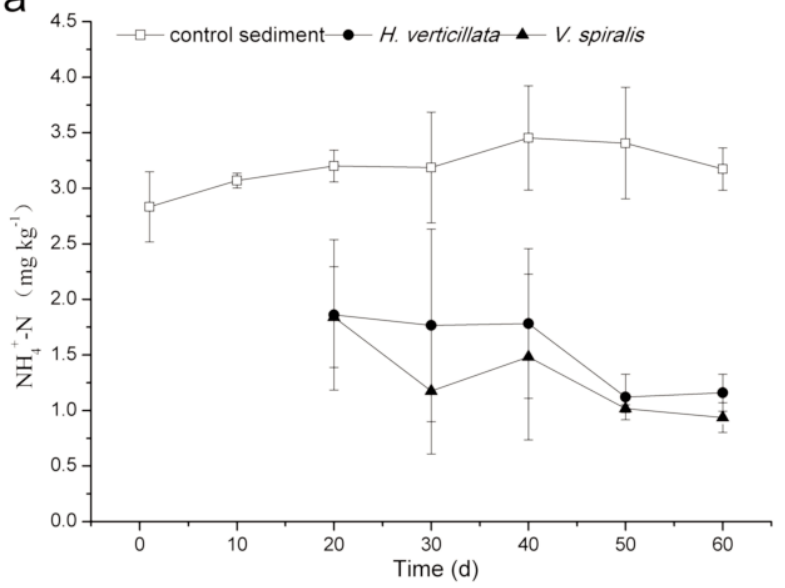

b

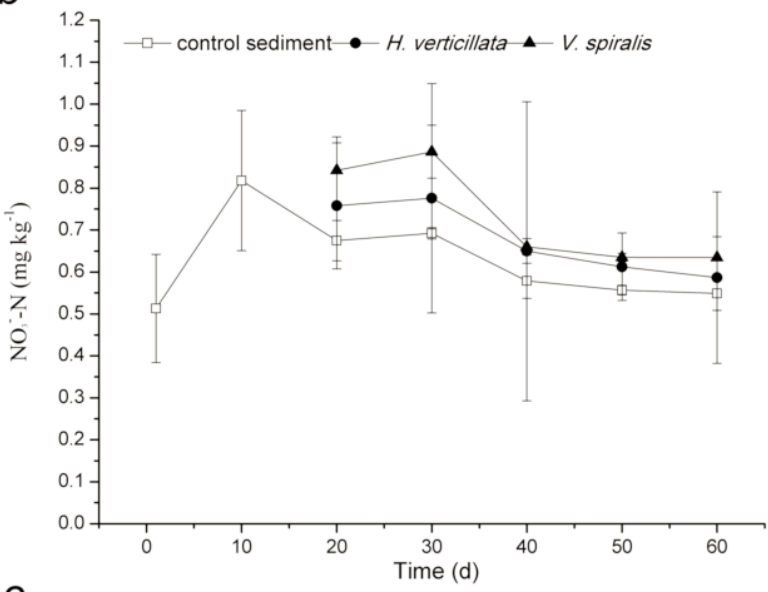

C

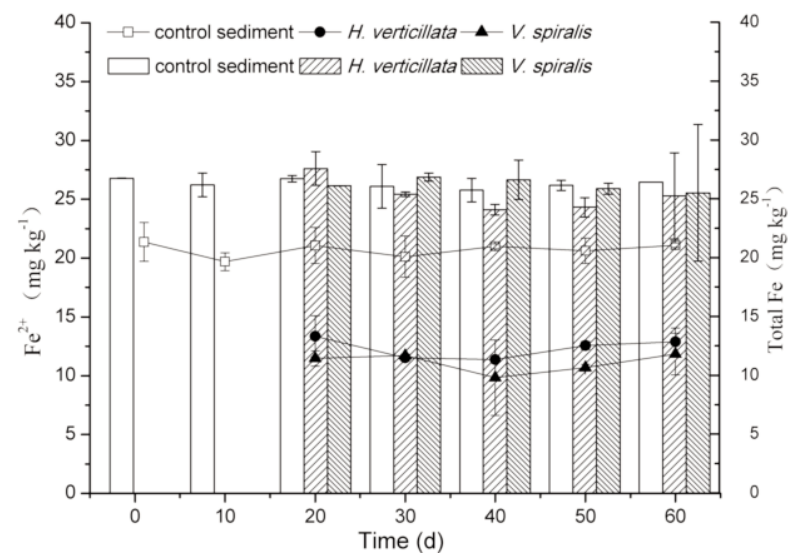

Fig. 4. Changes of chemical parameters in control and $H$. verticillata and $V$. spiralis rhizosphere sediment. 
Table 2. Contents of PLFAs and index of Shanon in sediment of the two plants.

\begin{tabular}{|l|l|l|l|}
\hline \multicolumn{1}{|c|}{$\begin{array}{c}\text { PLFA } \\
\text { (nmol. }{ }^{-1} \text { dry } \\
\text { sediment) }\end{array}$} & $\begin{array}{c}\text { Control } \\
\text { sediment }\end{array}$ & $\begin{array}{c}H . \\
\text { verticillata }\end{array}$ & $\begin{array}{c}V . \\
\text { spiralis }\end{array}$ \\
\hline Total biomass & $22.40 \pm 2.29^{\mathrm{a}}$ & $25.39 \pm 3.68^{\mathrm{a}}$ & $27.63 \pm 0.63^{\mathrm{b}}$ \\
\hline Total bacteria & $1.26 \pm 0.06^{\mathrm{a}}$ & $1.53 \pm 0.26^{\mathrm{a}}$ & $1.74 \pm 0.26^{\mathrm{b}}$ \\
\hline Gram-positive bacteria & $0.95 \pm 0.04^{\mathrm{a}}$ & $1.10 \pm 0.23^{\mathrm{a}}$ & $1.29 \pm 0.13^{\mathrm{b}}$ \\
\hline Gram-negative bacteria & $0.31 \pm 0.08^{\mathrm{a}}$ & $0.42 \pm 0.09^{\mathrm{a}}$ & $0.44 \pm 0.14^{\mathrm{a}}$ \\
\hline Fungi & $0.16 \pm 0.01^{\mathrm{a}}$ & $0.24 \pm 0.10^{\mathrm{a}}$ & $0.27 \pm 0.04^{\mathrm{a}}$ \\
\hline Actinomycetes & $0.18 \pm 0.01^{\mathrm{a}}$ & $0.18 \pm 0.01^{\mathrm{a}}$ & $0.28 \pm 0.01^{\mathrm{b}}$ \\
\hline Diversity index & $1.22 \pm 0.02^{\mathrm{a}}$ & $1.33 \pm 0.05^{\mathrm{a}}$ & $1.46 \pm 0.10^{\mathrm{b}}$ \\
\hline
\end{tabular}

means \pm SD with three replicates, small letters in the same row represent significant differences, $\mathrm{P}<0.05$

contained a variety of PLFAs, which were composed of saturated, unsaturated, and methyl-branched fatty acids (Fig. 5). Irrespective of the plants, a13:0, i14:0, a17:0,

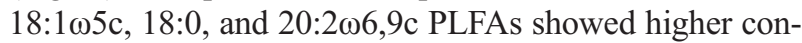
tents in rhizosphere sediment compared to control sediment; whereas 12:0, 14:0, i15:0, 16:1 $155 \mathrm{c}, 17: 1 \omega 7 \mathrm{c}$,

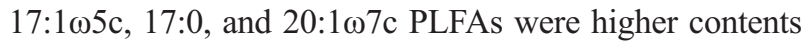
in control sediment compared to those of rhizosphere sediment (Fig. 5).

The contents of total biomass, total bacteria, grampositive bacteria, gram-negative bacteria, fungi, actinomycetes, and diversity index in the rhizosphere of $H$. verticillata and $V$. spiralis were higher than those in the control sediment (Table 2). In addition, although the rhizosphere of $H$. verticillata and the control sediment differed substantially in their PLFA contents (Fig. 5), there were no significant differences in their total bacterial, grampositive bacterial, gram-negative bacterial, fungal, actinomycic PLFA, and diversity index fractions (Table 2).
The results implied that the microbial community structure was similar. The proportion of fungal PLFAs was lower than that of bacterial PLFAs in rhizosphere sediment. The rhizosphere total biomass, bacteria, gram-positive bacteria, actinomycetes, and microbial diversity of $V$. spiralis were significantly higher than those of $H$. verticillata (Table 2).

\section{Discussion}

ROL from the roots of wetland and submerged plants, facilitated by extensive aerenchyma [3, 27], helps create oxidized rhizospheres. In the present study this is exemplified by the higher sub-surface Eh in the planted pots and the "oxidation ring" in Fig. 3a. Kludze et al. [18] showed that quantity of ROL to the rhizosphere was positively correlated with development of aerenchyma. The ability of ROL is strong when the aerenchyma is well developed [28]. The development of aerenchyma is considered the most important trait for a plant to tolerate sediment anaerobiosis [29]. In this experiment, V. spiralis had higher root porosity and inner oxygen than $H$. verticillata (Table 1). Similar results were also observed in the in situ measurement for the oxygen profile (Fig. 3a) by an oxygen microelectrode. Correspondingly, ROL of $V$. spiralis was greater than that of H. verticillata.

As oxygen is leaking from the roots, it is continuously consumed by microbial respiration and reoxidation of reduced compounds such as $\mathrm{NH}_{4}^{+}$and $\mathrm{Fe}^{2+}$ in sediment [3032]. In this experiment, the rhizosphere of $H$. verticillata had higher $\mathrm{NH}_{4}^{+}$and $\mathrm{Fe}^{2+}$ than $V$. spiralis, which were both significantly lower than the control sediment (Fig. 4). $V$. spiralis with higher root ROL had higher Eh in rhizosphere sediment than $H$. verticillata (Fig. 3b). The Eh values of planted sediment presented were higher than those of control sediment. These results clearly suggested that root ROL oxidized rhizosphere sediments and made rhizosphere Eh increase. Correspondingly, $\mathrm{NO}_{3}^{-}$of $H$. verticillata was

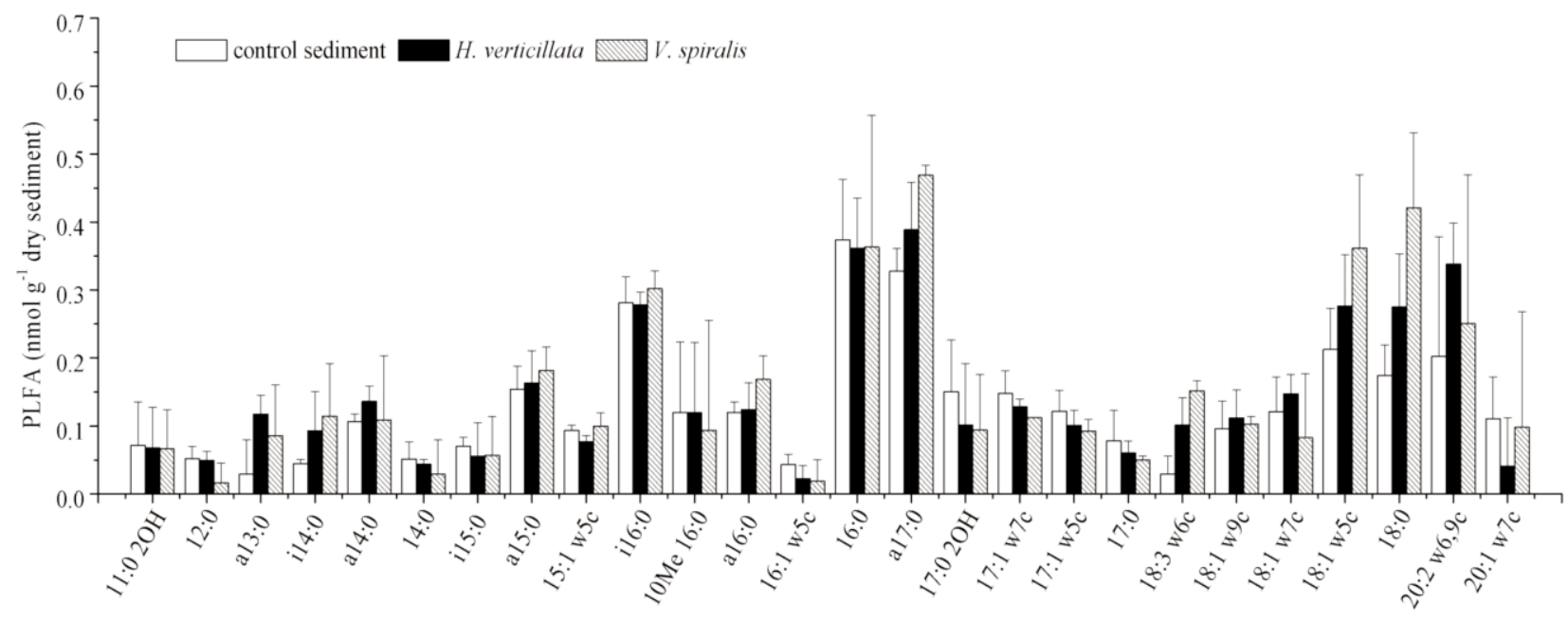

Fig. 5. Main composition of phospholipid fatty acids in control and $H$. verticillata and $V$. spiralis rhizosphere sediment. 
lower than that of $V$. spiralis, which were both higher than the control sediment. The results suggested that root ROL simultaneously enhanced rhizosphere nitrification [9]. In addition to nitrification, denitrification is another process in the soil N cycle. Kirk and Kronzucker [33] once established a model to estimate the potential for nitrification, denitrification, and nitrate uptake in the rhizosphere of wetland plants. The model showed that substantial quantities of $\mathrm{NO}_{3}^{-}$can be produced in the rhizosphere of wetland plants through nitrification. The model also showed that the rates of denitrification and subsequent loss of $\mathrm{N}$ from the soil remain small when $\mathrm{NO}_{3}^{-}$production and uptake were considerable. The calculation showed that wetland plants took up a large part of their $\mathrm{N}_{\text {as }} \mathrm{NO}_{3}^{-}$formed from $\mathrm{NH}_{4}^{+}$in the rhizosphere, without excessive losses of $\mathrm{N}$ through denitrification [9].

These processes are mainly affected by the microbial process. Root ROL oxidizes rhizosphere sediment and affects the microbial process. The total amount of PLFA serves as an estimate for sediment microbial biomass [34]. Rhizosphere sediment contained higher microbial biomass compared to the control sediment, which was likely due to greater availability of substrates for microbial growth [35, 36]. A variety of microbial PLFAs representative of total bacteria, gram-positive bacteria, gram-negative bacteria, fungi, and actinomycetes were identified from the sediment (Fig. 5). The proportion of fungal PLFAs was lower than that of bacterial PLFAs in all sediment samples (Table 2).

The plant species effect on microbial community structure in rhizospheres is due to differences in root ROL and root architecture $[10,35,37]$. While $V$. spiralis expected a higher amount of total PLFAs, total bacterial, gram-positive bacterial, and actinomycetes, PLFAs because $V$. spiralis presented a higher root biomass and ROL (Table 1) than $H$. verticillata. The rhizosphere microbial diversity of $V$. spiralis was significantly higher than that of $H$. verticillata (Table 2), suggesting that root ROL not only affected the population of rhizosphere microorganisms but also affected microbial community diversity [37, 38].

\section{Conclusion}

Using a combination of microelectrodes and PLFA analysis, root ROL and its effects on rhizosphere microarea were identified. The results showed that root and shoot biomass and root ROL increased with time. ROL of $V$. spiralis was significantly higher than that of $H$. verticillata. The order of sediment oxygen penetration depth was $V$. spirails $>H$. verticillata $>$ control sediment, and the order of the oxygen concentrations detected in the water layer and rhizosphere sediment was the same. The results showed that plants make the rhizosphere $\mathrm{NH}_{4}^{+}$and $\mathrm{Fe}^{2+}$ decrease and $\mathrm{NO}_{3}^{-}$increase. ROL enhanced rhizosphere microbial activity and affected the microbial composition. The contents of total biomass, total bacteria, gram-positive bacteria, gramnegative bacteria, fungi, actinomycetes, and diversity index in the rhizosphere of $H$. verticillata and $V$. spiralis were higher than those in the control sediment. $V$. spiralis might be expected to create significantly higher amounts of total PLFAs, total bacterial, gram-positive bacterial, and actinomycete PLFAs because of higher root biomass. The present study highlights that plant species with different root ROLs can change physicochemical parameters and microbial communities of the rhizosphere microarea.

\section{Acknowledgements}

This study was funded by the Major Science and Technology Program for Water Pollution Control and Treatment (No. 2013ZX07102005), and the National Natural Science Foundation of China (Nos. 31270509 and 31370504).

\section{References}

1. CROOKS J.A. Characterizing ecosystem-level consequences of biological invasions: the role of ecosystem engineers. Minireview. 153, 2002.

2. LAI W.L., ZHANG Y., CHEN Z.H. Radial oxygen loss, photosynthesis, and nutrient removal of 35 wetland plants. Ecol. Eng., 39, 24, 2012

3. ARMSTRONG, W. Aeration in higher plants. Advances in Botanical Research, (7), 225, 1979.

4. STOTTMEISTER U., WIEßNER A., KUSCHK P., KAPPELMEYER U., KÄSTNER M., BEDERSKI O., MÜLLER R.A., MOORMANN H. Effects of plants and microorganisms in constructed wetlands for wastewater treatment. Biotechnol. Adv., 22, (1-2), 93, 2003.

5. CHENG X.Y., WANG M., ZHANG C.F., WANG S.Q., CHEN Z.H. Relationships between plant photosynthesis, radial oxygen loss and nutrient removal in constructed wetland microcosms. Biochem. Syst. Ecol., 54, 299, 2014.

6. DE RIDDER-DUINE A.S., KOWALCHUK G.A., KLEIN GUNNEWIEK P.J.A., SMANT W., VAN VEEN J.A., DE BOER W. Rhizosphere bacterial community composition in natural stands of Carex arenaria (sand sedge) is determined by bulk soil community composition. Soil Biol. Biochem., 37, (2), 349, 2005.

7. EMERSON D., BELLOWS W., KELLER J.K., MOYER C.L., SUTTON-GRIER A., MEGONIGAL J.P. Anaerobic metabolism in tidal freshwater wetlands: II. Effects of plant removal on archaeal microbial communities. Estuar. Coast, 36, (3), 471, 2013.

8. HINSINGER P., BENGOUGH A.G., VETTERLEIN D., YOUNG I.M. Rhizosphere: biophysics, biogeochemistry and ecological relevance. Plant Soil, 321, (1-2), 117, 2009.

9. LI Y., WANG X. Root-induced changes in radial oxygen loss, rhizosphere oxygen profile, and nitrification of two rice cultivars in Chinese red soil regions. Plant Soil, 365, 115, 2013.

10. SMITH K.E., LUNA T.O. Radial oxygen loss in wetland plants: Potential impacts on remediation of contaminated sediments. J. Environ. Eng., 139, (4), 496, 2013.

11. PEDERSEN O., BINZER T., BORUM J. Sulphide intrusion in eelgrass (Zostera marina L.). Plant Cell Environ., 27, (5), $595,2004$. 
12. CAVAGLIERI L., ORLANDO J., ETCHEVERRY M. Rhizosphere microbial community structure at different maize plant growth stages and root locations. Microbiol. Res., 164, (4), 391, 2009.

13. YU H., YE C., SONG X., LIU J. Comparative analysis of growth and physio-biochemical responses of Hydrilla verticillata to different sediments in freshwater microcosms. Ecol. Eng., 36, (10), 1285, 2010.

14. SOANA E., NALDI M., BARTOLI M. Effects of increasing organic matter loads on pore water features of vegetated (Vallisneria spiralis L.) and plant-free sediments. Ecol. Eng., 47, 141, 2012

15. WANG A. L. Effects of emergent plant species and growth strategy on microbial community structure and diversity. Pol. J. Environ. Stud., 22, (5), 1563, 2013.

16. DONG W.Y., ZHANG X.Y., DAI X. Q., FU X.L., YANG F.T., LIU X.Y., SUN X.M., WEN X.F., SCHAEFFER S. Changes in soil microbial community composition in response to fertilization of paddy soils in subtropical China. Soil Biol. Biochem., 84, 140, 2014.

17. WILKINSON S.C., MANDERSON J., PSCARDELIS S., TISIAFOULI M., TAYLOR A., WOLTERS V. PLFA profiles of microbial communities in decomposing conifer litters subject to moisture stress. Soil Biol. Biochem., 34, 189, 2002.

18. KLUDZE H.K., DELAUNE R.D., PATRICK J.W.H. Aerenchyma formation and methane and oxygen exchange in rice. Soil Sci. Soc. Am. J., 57, (2), 386, 1993.

19. RUBAN V., LÓPEZ-SÁNCHEZ J.F., PARDO P., RAURET G., MUNTAU H., QUEVAUVILLER P. Harmonized protocol and certified reference material for the determination of extractable contents of phosphorus in freshwater sediments - A synthesis of recent works. Fresen. J. Anal. Chem., 370, 224, 2001.

20. MOSS M.L., MELLON M.G. Colorimetric determination of iron with 2, 2,-bipyridyl and with 2, 2, 2-terpyridyl. Industrial and Engineering Chemistry-analytical Edition, 14, (11), 862, 1942.

21. YANG X.E., LI H., KIRK G.J.D., DOBBERMANN A. Room-induced changes of potassium in the rhizosphere of Lowland Rice. Soil Sci. Plan., 36, 1947, 2005.

22. HOAGLAND D.R., ARNON D.I. The water-culture method for growing plants without soil. Calif Agr. Expt. Sta. Circ., 347, 1, 1950.

23. YUAN F., RAN W., SHEN Q., WANG D. Characterization of nitrifying bacteria communities of soils from different ecological regions of China by molecular and conventional methods. Biol. Fert. Soils, 41, (1), 22, 2005.

24. BOSSIO D., SCOW K. Impacts of carbon and flooding on soil microbial communities: phospholipid fatty acid profiles and substrate utilization patterns. Microb. Ecol., 35, 265, 1998.

25. FROSTEGÅRD A., BÅATH E. The use of phospholipid fatty acid analysis to estimate bacterial and fungal biomass in soil. Biol. Fert. Soil, 22, (1-2), 59, 1996.
26. ZELLES L. Phospholipid fatty acid profiles in selected members of soil microbial communities. Chemosphere, 35, (1-2), 275, 1997.

27. VISSER E.J.W., COLMER T.D., BLOM C. W.P.M. Changes in growth, porosity, and radial oxygen loss from adventitious roots of selected mono- and dicotyledonous wetland species with contrasting types of aerenchyma. Plant Cell Environ., 23, 1237, 2000.

28. COLMER T.D. Long-distance transport of gases in plants: a perspective on internal aeration and radial oxygen loss from roots. Plant Cell Environ., 26, 17, 2003.

29. LEMOINE D.G., MERMILLOD-BLONDIN F., BARRATSEGRETAIN M.H., CORINNE MASSÉ, MALET E. The ability of aquatic macrophytes to increase root porosity and radial oxygen loss determines their resistance to sediment anoxia. Aquat. Ecol., 46, 191, 2012.

30. PEZESHKI S.R., DELAUNE R.D. Soil oxidation-reduction in wetlands and its impact on plant functioning. Biology, $\mathbf{1}$, (2), 196, 2012.

31. BERG P., RØY H., JANSSEN F., MEYER V., JØRGENSEN B.B., HUETTEL M., BEER D.D. Oxygen uptake by aquatic sediments measured with a novel non-invasive eddy-correlation technique. Mar. Ecol. Prog. Ser., 261, 75, 2003.

32. YANG J.X., LIU Y., YE Z.H. Root-induced changes of pH, $\mathrm{Eh}, \mathrm{Fe}(\mathrm{II})$ and fractions of $\mathrm{Pb}$ and $\mathrm{Zn}$ in rhizosphere soils of four wetland plants with different radial oxygen losses. Pedosphere, 22, (4), 518, 2012.

33. KIRK G.J., KRONZUCKER H.J. The potential for nitrification and nitrate uptake in the rhizosphere of wetland plants: a modelling study. Ann. Bot., 96, (4), 639, 2005.

34. BÅ̊TH E., FROSTEGÅRD Á., FRITZE H. Soil bacteria biomass, activity, phospholipid fatty acid pattern, and $\mathrm{pH}$ tolerance in an area polluted with alkaline dust deposition. Appl. Environ. Microbiol., 58, 4026, 1992.

35. CHAUDHARY D.R., SAXENA J., LORENZ N., DICK L. K., DICK R.P. Microbial profiles of rhizosphere and bulk soil microbial communities of biofuel crops Switchgrass (Panicum virgatum L.) and Jatropha (Jatropha curcas L.). Applied and Environmental Soil Science, 2012, 1, 2012.

36. SÖDERBERG K.H. BÅÅTH E. Bacterial activity along a young barley root measured by the thymidine and leucine incorporation techniques. Soil Biol. Biochem., 30, (10-11), 1259, 1998.

37. CARRASCO L., GATTINGER A., FLIESSBACH A., ROLDAN A., SCHLOTER M., CARAVACA F. Estimation by PLFA of microbial community structure associated with the rhizosphere of Lygeum spartum and Piptatherum miliaceum growing in semiarid mine tailings. Microbial Ecol., 60, 265, 2010.

38. ZHANG C., LIU G., XUE S., XIAO L. Effect of different vegetation types on the rhizosphere soil microbial community structure in the Loess Plateau of China. J. Integr. Agr., 12, 2103, 2013. 